\title{
Family and Households in History
}

From March 18-20, 2004, the American University in Cairo (AUC) hosted its annual history seminar entitled "Family and Households in History." Dr. Nelly Hanna, chair of the Arab Studies department, welcomed the participants and audience and explained that the sessions would cover the institution of family from various perspectives and present its different roles and patterns throughout history.

The first session dealt with the family both philosophically and legally. Wolf Gazo (philosophy professor, AUC) tackled the issue of individual freedom and the concept of family morality. He compared the family in the Orient with that of Europe and North America, as well as each pattern's flexibility, including individual freedom. Edward Metenier (Institute Français du Proche Orient, Damascus) studied the pattern of one Iraqi family and made it his model for analyzing the strong ties between family members. He also focused on how one member's achievement of major prestige affected other members by raising them to high social positions. Thus, this one family enjoyed a high status for the whole nineteenth century, despite the political and economic changes in Iraq during that time.

After a coffee break, Judith Tucker (Georgetown University, USA) presented a paper on redefining the family and marital relations after modernization. According to her, legal reforms during the nineteenth and twentieth centuries, which were inspired by the western model, did not really revolutionize the family or redefine marital relations. Rather, these reforms transformed the most rigid Islamic traditions into laws that would be difficult to change. The seminar also considered different family patterns in other parts of world. Thus, Sonia Tamimy (Centre d'Etudes et de Documentation Economiques, Juridiques et Sociales [CEDEJ], Cairo) presented the views of famous French historians on the family and showed that the view of family changed according to changes in society and its morals. 
Turning from theoretical to real-life views, the third session concentrated on Arab family patterns throughout history. T. J. Fitzgerald, Harvard University, based his study of families and waqf in Aleppo on the seventeenth-century documents found in one of Aleppo's courts and dealing with the waqf deeds of one family after the changes brought about by the transfer of power from the Mamluks to the Ottomans after their conquest of Egypt and Syria in the sixteenth century. Sherry Gad Elrab (American University of Cairo) concentrated on the role of harem members, such as wives, daughters, and slave girls of the later `Abbasid caliphs, in shaping the policy of the caliphate, which was deteriorating due to the rise of other powers, such as the Buwayhids and the Seljuks.

On the second day, the sessions analyzed the growth of the Arab family during the nineteenth century. Alain Mikhail (California University) dealt with the issue of medicalizing the Egyptian family. Mikhail concentrated on the theories of Qasim Amin, known in Egypt as "the liberator of women," as expounded upon in his The New Woman. In his book, Amin encouraged women to become teachers or medical professionals. Basing his paper on Foucault's theory of power and medicine, Mikhail studies Amin's theory and the concentration of power in the family through the theory of its medicalization versus the state. In other words, this phenomenon at the turn of the century, within the context of the medical profession's growth and the spread of hospitals during the nineteenth century reveal the spread of the medical profession and hospitals in Egypt at that time, and show how it was both an integral part of Egyptian modernity and a form of resistance against it.

Studying the Egyptian family and its power relations with the state, Hanan Khloussy (New York University) studied the nuclearization of the family during the nineteenth century as the model for an ideal family set by the press and the state, despite the continuity of polygamy and extended families. Khloussy described this struggle between the state and the traditional family patterns as an attempt by the state to destroy any power rival, such as the extended family.

Dealing with another theme, the family as a trade institution, Pascale Ghazaleh presented a paper in which she discovered how import-export merchants in the first half of the nineteenth century chose to control who would inherit their wealth so that it would not necessarily go to their families, Qur'anic heirs, or agnates. Different strategies were discussed (e.g., endogamy, pious endowments, bequests and the use of patronage rights) to highlight the merchants' heirs and the implications of the process. 
The next session concentrated on the rise of large families in Egypt. The first paper dealt with Egypt's famous Coptic Wissa family. The Wissa brothers started as sellers of pins and ended up as major landowners in a period of rapid change during the nineteenth century. The paper studied the family's strategies for keeping its prestige intact through intermarrying with other noble families as well as forming binding ties with the state.

Noha Mokhtar, a graduate at Cairo University, dealt with how education and various influences affected the life of elite youth during the twentieth century. Mokhtar dealt with the western education received by the elite classes, how they reflected Egyptian society, and how they were seen by Egyptians. Sayed Ashmai (Cairo University) based his paper upon his examination of the Badrawi Ashour family, which was the largest land owner before the 1952 revolution. The paper examined the relations between the family and the state since the time of Khedive Ismail (183095), as well as the relation between the family and the peasants. The discussion turned more interesting with the presence of a professor of history, a descendant who presented the long-unheard voice of the landowning families since the revolution.

The last day witnessed two sessions under the theme of various family patterns. Mustafa el Labbad (Sharq Nameh magazine) discussed family power, which was one of the most important factors behind the Iranian revolution's success. The importance of the Shi ah family, that might have roots in different countries, still plays a crucial role in current Iranian politics. Dr. Tatania Summers (University of Alabama) discussed the ideal wife as presented in Homer's Odyssey, which went through different types of women, all rejected by Odysseus, to be the wife of a Greek man. Only Penelope, a weak and obedient wife who could subdue her power and property for the sake of her son, was considered a proper wife. Summers tried in her paper the characteristics of an ideal wife in archaic Greek culture.

The last paper, presented by Shawqi AlGamal (Institute of African Studies, Cairo University), discussed the colonial European historians' view of African families as barbaric. AlGamal presented the other view: the African family as seen by African historians. 